\title{
Determinants of Household Food Security among Southwest Ethiopia Rural Households
}

\author{
Mequanent Muche*, Birara Endalew , Tesfalem Koricho \\ Department of Agricultural Economics and Extension, College of Agriculture and Veterinary Medicine, Jimma University, Ethiopia
}

Copyright (C) 2014 Horizon Research Publishing All rights reserved.

\begin{abstract}
Aim of this study was to analyze determinants of household food security in Mana woreda of Jimma zone. As a specific objective, this study assessed food security status, identified determinants of food security and analyzed range of coping strategies practiced by food insecure households in the study area. Purposive sampling technique was used to select both Jimma Zone and Mana woreda. For this study a total of 70 households were selected randomly followed by probability proportional to sampling technique from two kebeles'. Both primary and secondary data were collected for this study. Primary data were collected by direct interview of sample respondents; whereas, secondary data were also collected from published and unpublished documents. Household caloric acquisition was employed to measure household food security in the study area. The collected data were analyzed by SPSS version 16.0. Regression model was used to reveal the effect of different variables on household food security. Accordingly, 42.9\% and $57.1 \%$ households were found to be food insecure food secure respectively. Out of nine explanatory variables, educational status of household head, family size, use of farm input and number of oxen owned by households were found to be significant at less than $10 \%$ probability level. Sale of livestock, borrow grains and cash from relative and reduce size of meal were identified at initial stage as first, second and third choice ; whereas, escaping of meal, ate less preferred food and reduce size of meal were also identified at severe stage as first, second and third choice in which food insecure households practiced during food shortage. To improve household food security, the farmer should use their oxen for cultivation purpose, use family planning and allocate their income for all expenditure; and the woreda education office together with minister of education should provide adult learning program to reduce illiteracy.
\end{abstract}

Keywords Determinant, Food Security, Regression Model

\section{Introduction}

The concept of food security was originated in the mid-1970s. The initial focus of food security was primarily on food availability and to some degree the price stability of basic food stuffs at the international and national level [1,2]. Thus, in the 1970s the issue of food security was the national food supply's capacity to meet the population's energy and nutrient needs. The concept of household food security has been understood by many development workers as the availability of food in the world market place and on the food production systems of developing countries [3, 4].

The term food security was introduced, evolved, developed and diversified by different researchers Since the World Food Conference in 1974. Food security is perceived at the global, national, household and individual levels. Food security at global level does not guarantee food security at the national level; and food security at the national level does not guarantee food security at the household [5].

Food insecurity is decreasing in the world where 925 million people are undernourished. Out of them, about 900 million people are living in developing countries [6]. The majority of food insecure and hungry people in the global context live in Asia and the Pacific (16\%), Sub-Saharan Africa (30\%), North Africa (8\%), and Latin America and the Caribbean (9\%). On the other hand, about 870 million people are estimated to have been undernourished in the period 2010-12. Out of them, about 852 million people are living in developing countries. This figure represents $12.5 \%$ of the global population [7]. Whereas, a total of 842 million people in 2011-13were estimated to be suffering from chronic hunger, regularly not getting food to conduct an active life. The total number of undernourished has fallen by $17 \%$ since 1990-92 [8].

The performance of agriculture in terms of feeding the country's population is poor. Currently in Ethiopia, there are more than 10 million people who have been affected by drought. Some 4.6 million people are threatened by hunger and malnutrition and require urgent food assistance. The deteriorating situation is compounded by high food prices [9].

Several studies indicated that, $41 \%$ of the Ethiopian population lives below the poverty line and 31.6 million people are undernourished. The latest undernourishment 
numbers show a positive trend (1990-92:71\% of the population; 1995-97: 64\%; 2000-02: 50\%; 2004-06: 44\%) [6]. the concentrations of food insecurity and malnutrition are prevalent in rural areas, with a population of six to seven million chronically food insecure and up to 13 million seasonally food insecure [10].

Different factors were identified in various studies that aggravate food insecurity problem in Ethiopia. These are: poor soil fertility, land shortage, occasional droughts, and degradation of farm lands, frost attack, and chronic shortage of cash income, poor farming technologies, weak extension services, high labor wastage, and poor social and infrastructural situation. The combinations of those factors have resulted in serious and growing problem of household level food insecurity in Ethiopia 11, 12].

Through time, poor and hungry populations become less flexible to stress and disasters as they rely a great deal on the natural environment and lack the capacity and the resources required recovering from disasters [13]. In Ethiopia, the seriousness of food shortage problem varies from one area to another, depending on the state of the natural resources and the extent of development of food shortage [14].

\section{Methodology}

\subsection{Description of the Study Area}

Mana is one of the woredas in the Oromiya region of Ethiopia. Part of the Jimma Zone, Mana is bordered on the south by Sekachekorsa, on the west by Gomma, on the north by Limmukossa, and on the east by Kersa [15]. It is classified in to dega (12\%), woinadega (63\%) and kolla (25\%) agro-climatic zones. Average rainfall is $1,467 \mathrm{mms}$. The 2007 national census reported a total population for this woreda of 149,631, of whom 76,218 were men and 73,414 were women; 4,393 or $3 \%$ of its population were urban dwellers [16].

Mixed cropping system is mainly practiced in the District. Maize, teff, sorghum, barley, wheat, coffee, chat and horse bean are the most widely cultivated crops in the district. Chat and coffee are important cash crops. The households purchase cereals from the market through the income they generated from sale of coffee and chat produce. This implies that those perennial crops encourage farm households to be food secured [17].

\subsection{Sampling Procedure}

A multistage sampling technique was used for this study; where in the first step Jimma Zone was selected purposively, and second step Mana Woreda was selected to address food security issue. Then at the third step, two Kebeles namely: Gube Muleta and Lemi Lelesa were selected by using simple random sampling followed by probability proportional to sampling technique. A total of 38 and 32 households were selected from LemiLelesa and GubeMuleta kebele, respectively.

\subsection{Method of Data Collection}

Both primary and secondary data were collected from different sources to identify important variable that may affect household food security. To generate primary data, a semi structured questionnaire was used to collect quantitative data through a household survey involving household heads and their spouses from two kebeles (Gube Muleta and Lemi Lelisa). The survey covered a total of 70selected households (67 men headed household sand 3 female headed households). The survey was conducted once that was done once. data were collected on demographic characteristics, asset possession, off-farm income (portion of farm household income obtained off the farm, including nonfarm wages and salaries, pensions, and interest income earned by farm families) ; farm income( profit and losses incurred through the operation of a farm or income obtained from farm activities) and Non farm income (income obtained from nonfarm activities such as petty trading nonfarm employment etc...); livestock and oxen ownership, farm income, off-farm income and non-farm income, , food consumed by the household for the household in specific period( seven day recall). On the other hand, additional data on resource endowment, institutional factors such as access to credit, use of external farm inputs were also gathered. Data were also collected through Focused Group Discussion and key informants interview subsequent to the survey.

\subsection{Method of Data Analysis}

To identify food secure and insecure households, food items consumed for seven days were obtained from respective households. Household caloric acquisition was used to measure food security in the study area. Then after it was converted to $\mathrm{kcal} / \mathrm{day}$ basis and it has been made ready to calculate $\mathrm{kcal} / \mathrm{day} / \mathrm{AE}$, the results obtained were compared with the minimum requirements per day per adult equivalent (A.E). Accordingly, the household whose caloric consumption greater than or equal to $2100 \mathrm{Kcal} / \mathrm{day} / \mathrm{AE}$ was categorized as food secure; on the other hand, households whose consumption less than $2100 \mathrm{Kcal} / \mathrm{day} / \mathrm{AE}$ was categorized as food insecure.

The collected data were analyzed by Statistical Package for Social Sciences version 16.0.

To estimate food insecurity incidence, depth and severity, Foster Greer Thorbeck (FGT) was employed.

$$
P_{\alpha}=\frac{1}{N} \sum_{I=1}^{M}\left(\frac{z-y_{i}}{z}\right)^{\alpha}
$$

Where, $\mathrm{P}=$ number of food insecure households

$\mathrm{Z}=$ the minimum requirements per day per adult equivalent $(2100 \mathrm{Kcal} / \mathrm{day} / \mathrm{AE})$

$\mathrm{Yi}=$ the calorie intake of each food insecure households $\alpha=$ weight attached to food insecurity

$\mathrm{N}=$ total sample size 
The household is food secure when $\mathrm{Yi} \geq \mathrm{Z}$ for this model. Within this FGT index, we compute the three most commonly employed indices: head count ratio, food insecurity gap and squared food insecurity gap. The head count ratio indicated the number of households whose caloric intake is less than the minimum requirements. On the other hand, food insecurity gap measure, on average, how far the food insecure households are below the cut off value; and square food insecurity gap is a measure closely related to severity of food insecurity gap but giving those further away from the minimum level a higher weight in aggregation than those closer to the subsistence level[18].

Binary logistic regression model was used to address the objective of this study. Household food security is a dependent variable for this model.

Mathematically

$$
p=F(Z)=\frac{1}{1+e^{-Z}}
$$

Where

$\mathrm{p}=$ probability to be food secure or insecure

$\mathrm{F}=$ logistic function

$Z=\beta_{1}+\beta_{2} X, \mathrm{Z}=1$ food secure $\mathrm{z}=0$ food insecure

$\beta_{1}$ and $\beta_{2}$ are coefficients of explanatory variables

$\mathrm{X}$ is predictor variables

$\mathrm{e}=$ error term

\subsection{Hypothesis}

The dependent variable for this study is household food security. It was hypothesized to be a function of the following variables.

Age of household head: is a continuous explanatory variable measured by year. Older people have relatively richer experiences of the social and physical environments and greater experience of farming activities. Older household heads are expected to have better access to land than younger heads, because younger men either have to wait for land redistribution, or have to share land with their families [20]. Thus, it is hypothesized that age of the household heads and household food security are positively correlated.

Educational status of household head: is dummy variable and an important determinant of household food security status in that; educated households have a better chance of adopting soil conservation measures which in turn increases crop production [21]. Educated household head has the capacity to innovate and to adopt timely technology and has better understanding of the cash crops that can help them to have a better income than the non-educated households [22, 23]. Thus, education status is hypothesized to have a positive effect on household food security.

Family size refers to the total number of household members who lived and eat with household at least for six months. It is an important variable which determines the state of household food security and expected to have negative effect on household food security [24, 25]. According to reviewed literatures, increasing family size tends to exert more pressure on consumption than the labor it contributes to production [26].

Farm land size is continuous explanatory variable and an important determinant of household food security. Farm size is the total area of land cultivated to food and cash crop by households, measured in hectares. Positive relationship has been established between farm size and improvement in households' income and food security [27, 28]. It is, therefore, expected of a household with a larger farm size to be more food secure than a household with a smaller farm size.

Dependency ratio is measured as total household size divided by the number of individuals working to support the household. Due to the scarcity of resources, an increase in household size especially the non-working members put pressure on consumption than production [25, 29, 30]. An increase in the number of non-working member of household or dependency ratio increases the food insecurity level of household [31].

Number of oxen owned: Oxen are the most important means of land cultivation and basic factors of production. Households who own more oxen have better chance to escape food shortages since the possession of oxen allows effective utilization of the land and labor resources of the household [32,33,34]. Positive correlation is expected between number of ox/oxen owned and household food security.

On farm income: This source of income is collected from sale of crop produce, sale of livestock and livestock product and hiring of agricultural land. The more household head engage in gainful employment, the higher he/she earns income and the greater the chances of being food secure [35].

Use of farm inputs refers to use of chemical fertilizer, improved seed, pesticide and herbicide. The amount of farm input used was converted to monetary value based on market price during time of the survey. A household who could have used farm inputs was hypothesized to have positive relation with food security status because he/she produce more [36].

Credit access: Credit serves as a means to boost production and expand income generating activities. Thus, a household which has access to credit does initiate investment in farm and non-farm activities and achieve food security. Thus, it is hypothesized that credit access has positive relation with household food security [37].

\section{Result}

Accordingly, 42.9\% households were food insecure; whereas, $57.1 \%$ of them were food secure.

\subsection{Descriptive Statistics of Continuous Variables}

The mean ages of the food insecure households were 
45.1years with standard deviation of 12.6 and the food secured household also 41.5 years with standard deviation of 10.2 (table 1).

The mean number of family size of food insecure households was 6.1 with standard deviation of 1.7; and for food secure households 5.1 and 1.4, respectively (table 1). The survey indicated that there is significant mean difference between households because of family size at $p<0.01$.

This analysis aimed to see whether there is a significant difference in the presence of dependent members between the food insecure and the food secured households. The mean number of dependents of food insecure households was 0.3 with standard deviation of 0.3 ; and 0.2 and 0.1 for food secure households, respectively (table 1). The independent t-test shows significant difference in the presence of dependent members with in the household at $\mathrm{p}<0.1$.

The average farm land size owned by food insecure households was 1.4 ha with standard deviation of 0.7 ; where as, 1.6ha with standard deviation of 0.8 for food secure households (table1).

On average, food insecure and secure households earned total cash income of 10,922 and 12,717ETB (Ethiopian Birr) from on farm source, respectively (table 1).

The averages off farm income generated by food insecure and secure households were 176.7 and 1,994 ETB from off farm income, respectively (table 1). The independent t-test showed that there is significant difference between the food secure and insecure households at $p<0.05$. This finding is statistically significant at $\mathrm{p}<0.05$.

Non-farm income is the third source of household income generated from petty trade, handicraft, and sale of charcoal and construction work during off farm season in the study area. On average food insecure and secure households generated 1447.5 and 2085 ETB from non-farm income, respectively.

The average number of oxen owned by food insecure household was 0.8 with standard deviation of 0.7 ; and 1.1 with standard deviation of 0.8 for food secure households (table1).

Table 1. descriptive statistics of continuous variables

\begin{tabular}{|c|c|c|c|c|c|c|c|c|c|}
\hline \multirow[b]{2}{*}{ Variable } & \multicolumn{8}{|c|}{ Food Security Status } & \multirow{2}{*}{$\mathrm{t}$-value } \\
\hline & Min & Max & Mean & SD & Min & Max & Mean & SD & \\
\hline Age & 25 & 80 & 45.1 & 12.6 & 28 & 65 & 41.5 & 10.2 & 1.31 \\
\hline Family Size & 3 & 12 & 6.1 & 1.72 & 2 & 8 & 5.1 & 1.4 & $2.82 * * *$ \\
\hline Dependeny. $R$ & 0 & 1.9 & 0.3 & 0.3 & 0 & 0.5 & 0.2 & 0.1 & $1.98^{*}$ \\
\hline land size & 0.25 & 3 & 1.4 & 0.7 & 0.25 & 4 & 1.6 & 0.8 & 1.31 \\
\hline On-Farminc & 3500 & 24250 & 10922 & 4462 & 800 & 40000 & 12717 & 7314.6 & -1.19 \\
\hline Off-Farminc & 0 & 2400 & 176.7 & 611.2 & 0 & 10800 & 1994 & 3587.4 & $-2.74 * *$ \\
\hline Non-Farminc & 0 & 14800 & 1447.5 & 3458.7 & 0 & 10000 & 2085 & 3439.7 & -0.77 \\
\hline ox & 0 & 2 & 0.8 & 0.7 & 0 & 2 & 1.1 & 0.8 & -1.53 \\
\hline
\end{tabular}

***, ** and* significant $\mathrm{p}<0.01, \mathrm{P}<0.05$ and $\mathrm{p}<0.1$ respectively

Source: own survey (2014)

Table 2. descriptive statistics of discrete variables

\begin{tabular}{|c|c|c|c|c|}
\hline \multirow[b]{2}{*}{ Variable } & \multirow[b]{2}{*}{ Categories } & \multicolumn{2}{|c|}{ Food Security Status } & \multirow[b]{2}{*}{ Chi-square } \\
\hline & & $\begin{array}{c}\text { Food Insecure } \\
\mathrm{N}=30(\%)\end{array}$ & $\begin{array}{l}\text { Food Secure } \\
\mathrm{N}=40(\%)\end{array}$ & \\
\hline Sex & Female & 2.9 & 1.4 & \\
\hline Marital status & Married & 40 & 54.3 & 0.09 \\
\hline \multirow[t]{2}{*}{ Educational Status } & Literate & 12.9 & 32.9 & $5.22 * *$ \\
\hline & Illiterate & 30 & 24.3 & \\
\hline Farm Input & Yes & 30 & 40 & 0.0 \\
\hline
\end{tabular}

**And *Significant $\mathrm{P}<0.05$ and $\mathrm{p}<0.1$, respectively

Source: own survey (2014) 


\subsection{Descriptive Statistics of Discrete Variables}

The survey result indicated that, $95.7 \%$ and $34.3 \%$ households were male and female headed households, respectively. Among male headed households $40 \%$ and $55.7 \%$ were found to be food insecure and secure, respectively; on the other hand, $2.9 \%$ and $1.4 \%$ were food insecure and secure from female headed households, respectively (table 2 )

From table2, 94.2\% and5.8\% household heads were found to be married and divorced. From married household heads $40 \%$ and $54.3 \%$ were food insecure and secure households; whereas, $2.9 \%$ for divorced households were food insecure and secure equally (table 2).

The result in table 2 revealed that $45.7 \%$ and $54.3 \%$ households were literate and illiterate. From literate household heads, $12.9 \%$ and $32.9 \%$ households were food insecure and secure, respectively. Where as, $30 \%$ and $24.3 \%$ of illiterate household heads were food secure and insecure respectively. Education is an important variable for household food security because literate household head shape the activity of his/her family to involve in different income generating activity. This finding is statistically significant at $\mathrm{p}<0.05$.

From the households interviewed, $70 \%$ and $30 \%$ households were found to be users and non-users of farm inputs. From those who use farm inputs, 30\%and $40 \%$ were found to be food insecure and secure households, respectively: on the other hand, from non-users of farm input $12.9 \%$ and $17.1 \%$ was food insecure and secure, respectively (table 2).

The result revealed that, $62.9 \%$ and $37.1 \%$ were users and non-users of credit access. Among the food insecure households, $22.9 \%$ and $20 \%$ were found to be users and non users of credit access; and $40 \%$ and $17.1 \%$ of food secure households were users and non users of credit access (table2).

Table 3. Extent of food insecurity

\begin{tabular}{c|c}
\hline Type & Percent \\
\hline Incidence Food Insecurity(Head Count Ratio) & 42.9 \\
Depth Food Insecurity(Food Insecurity Gap) & 4.4 \\
Severity Food Insecurity(Squared Food Insecurity Gap) & 0.4 \\
\hline
\end{tabular}

\subsection{Extent of Food Insecurity}

Table 3 revealed the FGT indices: incidence of food insecurity, depth of food insecurity and severity of food insecurity at $\alpha=0,1$ and 2 , respectively. The result of FGT model indicated that $42.9 \%$ of households were living below minimum requirements per day per adult equivalent. To know how far the households from minimum requirements per day per adult equivalent, food insecurity depth was calculated. From the result, on average, $4.4 \%$ of households were far from recommended caloric intake for active and healthy life. The severity of food insecurity is measured as a weighted average of the square distance below minimum requirement. As the survey result indicated, the severity of food insecurity is $0.4 \%$.

\section{Discussion}

\subsection{Determinants of Household Food Security}

Out of nine variables included in the model, four explanatory variables were found to be significant. The possible explanations of the significant variables are as follows.

Educational status of the household is positively related with household food security and statistically significant at $\mathrm{p}<0.1$ consistent with the hypothesized effect. It is an important determinant of household food security because an educated household is more sensitive to adopt technology to maximize the output he/she generated from farm activities. This contributed directly for household food security. The odd ratio in favor of food secure is increased by 4.29 as the household is educated. This study is in line with the previous studies $[38,39]$.

Family size is statistically significant at $p<0.05$ and exhibits a negative relationship with household food security similar to the hypothesized effect. This indicated that, most of the family members are inactive age group that has no contribution for production rather than consumption. Large family size creates more pressure on household food security because more food and non food expenditure is spent for them increases. As family size increased by one, the odd ratio in favor of food secure decreased by 0.57 . This study is congruent with the previous studies [40, 41, 42].

The coefficient of use of farm input is negative and statistically significant at $\mathrm{p}<0.05$ in contradict with the hypothesized effect. This implies that farm input has negative effect on household food security. Farm inputs are highly expensive in price; as a result, the farmers invest their income for farm input by ignoring other expenditures and sold their crop produce to purchase those farm inputs for his/her land when their cash income is not enough to purchase farm inputs. The odds ratio in favor of being food secure decrease by a factor of 0.15 as a farmer gets access to farm inputs. This study is contradicted with previous studies [36].

The coefficient of number of oxen owned by the household is positive and statistically significant at $\mathrm{p}<0.1$. Household food security and number of oxen owned is positively related. The household who has oxen can generate income by cultivating others land through rent and from his land. This contributes more for household food security. The odd ratio in favor of being food secure is increased by 2.32 when the number of oxen is increased by one. This study is in line with the previous studies [34, 43]. 
Table 4. result of logit model

\begin{tabular}{|c|c|c|c|c|c|}
\hline Variable & $\mathrm{B}$ & S.E. & Wald & Sig. & $\operatorname{Exp}(B)$ \\
\hline Constant & 5.72 & 2.54 & 5.06 & 0.02 & 303.69 \\
\hline AGEOFHHH & -0.06 & 0.04 & 2.13 & 0.14 & 0.94 \\
\hline EDUSTHHH(cat) & $1.46^{*}$ & 0.80 & 3.28 & 0.07 & 4.29 \\
\hline FAMILSIZ & $-0.56 * *$ & 0.26 & 4.67 & 0.03 & 0.57 \\
\hline DEPENDRA & -3.40 & 2.69 & 1.59 & 0.21 & 0.03 \\
\hline LANDINHAC & 0.14 & 0.41 & 0.11 & 0.74 & 1.15 \\
\hline FARMINPU(cat) & $-1.91 * *$ & 0.93 & 4.21 & 0.04 & 0.15 \\
\hline ONFARINC & 0.00005 & 0.0001 & 0.50 & 0.48 & 1.00 \\
\hline CREDITAC(cat) & 0.40 & 0.72 & 0.31 & 0.58 & 1.49 \\
\hline OX & $0.84 *$ & 0.46 & 3.37 & 0.07 & 2.32 \\
\hline -2Log Likelihood ratio & & & & & 69.18 \\
\hline Pearson chi-square & & & & & $26.43 * *$ \\
\hline $\mathrm{R}^{2}$ (Nagelkerke) & & & & & 0.42 \\
\hline
\end{tabular}

** And* significant at $\mathrm{p}<0.05$ and $\mathrm{p}<0.1$

Source own survey (2014)

\subsection{Coping Strategy}

The coping strategy in which food insecure households followed were classified in to two stages for this study with three choices for each. These are at the initial stage of food shortage and at the severe stage of food shortage with first, second and third choice for each stage. The survey result indicated that, $63.3 \%, 73.3 \%$ and $83.3 \%$ of food insecure households practiced sale of livestock, borrow grains or cash from relative and reduce size of meal as 1 st, 2 nd and $3 \mathrm{rd}$ choice at initial stage, respectively. Whereas, $53.3 \%, 30 \%$ and $43.3 \%$ of the practiced escaping of meal, ate less preferred food and reduce size of meal at severe stage of food shortage as 1 st ,2nd and 3rd choice, respectively.

\section{Conclusion and Recommendation}

This finding concluded and recommended the following core idea related to the issue of household food security based on the result obtained and reviewed document.

Family size was found to be negatively related with household food security. The main case behind is that as family size increase the chance of obtaining sufficient food decreases .Due to this reason, having more household size aggravate the problem of obtaining adequate food for healthy and active life; as a result the household head should use family planning service to limit their family size.

Education is an important variable for household food security because it is found to be statistically significant and positively related with household food security. Therefore the minister of education in collaborated with the Woreda education office should provide adult learning programme for those illiterate (54.3\%) households which is already set as national adult learning program.

Use of farm input was found to be negatively related and statistically significant. This means as the farmer gets access to farm input; he/she become food insecure. This is due to the income generated from different source is invested for farm input. Therefore, the farmer should allocate their income not only for farm input but also for household consumption.

Number of oxen owned by the households and household food security were found to be positively related and statistically significant. As a result, the farmers should use their oxen for cultivation of crops to get the required yield from crop cultivation and engaged in income generating activity through renting of land from other farmers so as to be food secured.

\section{Acknowledgements}

We are grateful to farmers of the study area who made this study possible. We acknowledge the staff of Department of Agricultural Economics, Jimma University for facilitation render to us. We also like to forward our thanks to Development Agents and Local administrators in the area for facilitation of the work. The financial support from Jimma University, College of agriculture and Veterinary Medicine which enabled us to conduct the study is greatly acknowledged.

\section{REFERENCES}

[1] Clay E "Food Security: Concepts and Measurements. Paper for FAO Expert Consultation on Trade and Food Security", Rome, 2002.

[2] FAO "Assessment of the world food security situation" . Committee on World Food Security, $31^{\text {st }}$ session, 23-26 May, 2005.

[3] FANTA 2003 "Food and Nutrition Technical Assistance 
Project and Food Aid Management. Food Access Indicator Review “, Washington, D.C, 2003.

[4] Bedeke S "Food insecurity and copping strategies: a perspective from Kersa district,.Food Science and Quality Management", 2012; 5.

[5] Duffour K "Budget Statement and Economic Policy of the Government of Ghana",2011;P.49.

[6] FAO "The state of food insecurity in the world, Food and Agriculture Organization of the United Nations" , Rome, 2010.

[7] FAO "The State of Food Insecurity in the World,Food and Agriculture Organization of the United Nations", Rome, 2012.

[8] FAO The state of food insecurity in the world.The multiple dimensions of food security, 2013.

[9] WFP Food security and vulnerability in Addis Ababa, 2009.

[10] Bill and Melinda Gates Foundation "Accelerating Ethiopian Agriculture Development for Growth, Food Security and Equity", Addis Ababa, 2010.

[11] Hussein B "Major Causes of Household Food Insecurity in Wuchale-Jidda Woreda, Oromiya National Regional State". MA Thesis, Addis Ababa University, 2006.

[12] DO Gilligan Hoddinott A S and Taffesse"An Analysis of Ethiopia's Productive Safety Net Program and Its Linkages", International Food Policy Research Institute, Washington, D.C, 2008.

[13] Oluoko O and Alice A "Vulnerability and Adaptation to Food Insecurity and Poverty in Kenya". Annals of theAssociation of American Geographers, 2011; Vol. 101 pp1-20.

[14] Amsalu M, Bekabil F and Beyene T "Empirical analysis of the determinants of rural household's food security in Southern Ethiopia: The case of Shashemene District".Basic Research Journal of Agricultural Science and Review, 2012.ISSN 2315-6880; 1(6): 132-138.

[15] On Line http://en.wikipedia.org/wiki/Mana_\%28woreda\%29 4 (accessed in 15/3/2014).

[16] Population and Housing Census of Ethiopia Results for Oromia Region, 2007: 1, Tables 2.1, 2.5, 3.

[17] Oromia Coffee Cooperative UnionSocio-economic profile of the East Wellega Zone. 2006.

[18] Hoddinott J "Method for Rural Development projects: Food Security in practice", IFPRI, Washington D.C, Florida University, 2001; 1: 80-100.

[19] Gujarati "Basic Econometrics Fourth Edition McGraw Hill", New York, 2004.

[20] Haile K, Alemu G and Kudhlande G "Causes of Household Food Insecurity in Koredegaga Peasant Association, Oromia Zone, Ethiopia”.working paper, 2005.

[21] Million T and Kassa B "Adoption of Soil Conservation Measures in Southern Ethiopia”. Journal of Agriculture and Rural Development in the Tropics and Subtropics, 2004; 105(1): 49-62.

[22] Fekadu N "Determinants of Household Food Security the case of Bulbula in Adami-Tulu JidoKombolcha, Oromia Region". M.Sc Thesis Addis Ababa University, 2008.

[23] Paual A "Changes in household food security and poverty status in PROSAB area of Southern Borno State", Nigeria, 2009.

[24] Fekadu B and Mequanent M "Determinants of Food Security among Rural Households of Central Ethiopia". Quarterly Journal of International Agriculture, 2010; 49(4): 299-318.

[25] Mequanent M "Determinants of household food security and coping strategy: the case Adabergaworeda, Ethiopia". Haramaya University, 2009.

[26] Tsegay G "Determinants of food security in rural households of Thetigray region". M.Sc thesis addisababaUniversity, 2009

[27] Jayne TS, Marther D and Mghenyi E "Smallholder Farming in Difficult Circumstances", in Proceedings of a Research Workshop, 2005; 103- 123.

[28] Yilma M "Measuring rural household food security status and its Determinants in the BenishangulGumuz region". Alemaya University, 2005.

[29] Aschalew FA "Determinants and dimensions of household food Insecurity in Dire Dawa city, Ethiopia". Alemayauniversity, 2006.

[30] Feleke S, Kilmer R, and Gladwin C "Determinants of food security in Southern Ethiopia". Agricultural Economics Journal, 2005; 33: 351-363.

[31] Ojogho O "Determinants of Food Insecurity among Arable Framers in Edo State, Nigeria". Agricultural Journal, 2010; 15: 151-156.

[32] Getinet KA "Linking small-scale irrigation and household food Security in drought prone area of north east Ethiopia: a case of Gubalaftoworeda". M.Sc thesis Addis Ababa University, 2011.

[33] GuledA "Food Insecurity and Copping Strategies of Agro-Pastoral Households in Somali Region, Ethiopia". M. Sc. Thesis Haramaya University, 2006.

[34] Tesfaye K "Household food insecurity in Dodotasire district, Arsi zone: coping strategies and policy options". M. Sc Thesis Alemaya university, 2005.

[35] Arene CJ and Anyaeji J "Determinants of Food Security among households in Nigeria". Pakistan Journal of Social Sciences, 2010; 30: 9-16.

[36] Genene T "Farmers' perceptions of land degradation and Determinants of household food security at middle catchment of Bilate Watershed". M.Sc Thesis Alemaya university, 2006.

[37] Devereux S "Livelihood insecurity and social protection". Development Policy Review, 2001; 19 (4): 507-519.

[38] Aschalew FA "Determinants and dimensions of household food Insecurity in dire dawa city, Ethiopia". Alemayauniversity, 2006.

[39] Amsalu and Wendimu"The Determinants of RuralHouseholds' Vulnerability toFood Insecurity in South Western Ethiopia”. Journal ofBiological andChemical Research, 2013; 31(1): 62-72. 
[40] Ejigayhu ST "Determinants and dimensions of household food insecurity in Addis Ababa City, Ethiopia" .M.Sc Malawi university, 2011 .

[41] Bogale A and Shimelis A "Household level determinants of food insecurity in rural areas of Dire Dawa, Eastern Ethiopia".
African Journal of Food and Agriculture, Nutrition and Development, 2009; Volume 9, No 9.

[42] Mulugeta TW "Determinants of household food security in Eastern Oromia, Ethiopia”.M.Sc Thesis Alemaya University, 2002 